\title{
IDIOMATIC EXPRESSION IN UMPAMA PAKPAK WEDDING CEREMONY
}

\author{
AN ARTICLE \\ Submitted in Partial Fulfillment of the requirements for the Degree of \\ Sarjana Sastra
}

By:

AGUNI BERUTU

Registration Number : 2122220001

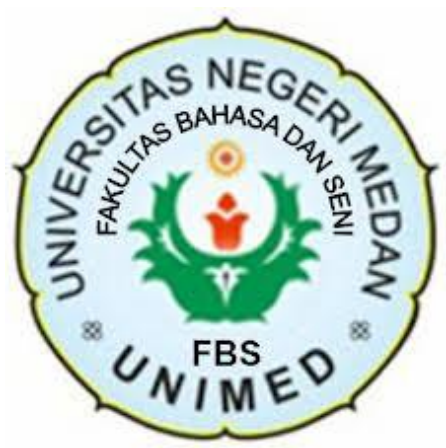

ENGLISH AND LITERATURE DEPARTMENT

FACULTY OF LANGUAGES AND ARTS

STATE UNIVERSITY OF MEDAN

2017 
ARTIKEL

\title{
IDIOMATIC EXPRESSION IN UMPAMA PAKPAK WEDDING CEREMONY
}

\author{
Disusun dan Diajukan oleh: \\ Aguni Berutu
}

NIM. 2122220001

Telah diverifikasi dan dinyatakan memenuhi syarat

Untuk diunggah pada jurnal online

Medan, Juli 2017

Menyetujui

Dosen Pembimbing I,

Dosen Pembimbing II,

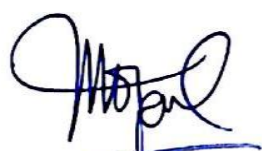

Dra. Meisuri, M.A

NIP. 19610523198703200

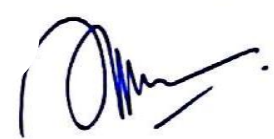

Juli Rachmadani Hsb, S.S., M.Hum. NIP. 198207112008012008

Ketua Prodi Sastra Inggris

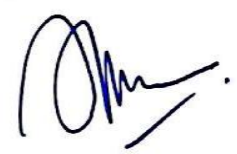

Juli Rachmadani Hsb, S.S., M.Hum.

NIP. 198207112008012008 


\title{
IDIOMATIC EXPRESSION IN UMPAMA PAKPAK WEDDING CEREMONY
}

\author{
*Aguni Berutu \\ **Dra. Meisuri, M.A \\ **Juli Rachmadani Hsb, S.S,. M.Hum.
}

\begin{abstract}
Aguni Berutu. 2122220001. Idiomatic Expression in Umpama Pakpak Wedding Ceremony. A Thesis. English and Literature Department. Faculty of Languages and Arts. State University of Medan. 2017

This study deals with idiomatic expression in Pakpak wedding ceremony. The objectives of this study were to find out the categories of umpama, to describe the meaning of umpama, and to find out the dominant category of umpama used in Pakpak wedding ceremony. This research was conducted by using descriptive qualitative design. The data were 25 utterances of idiomatic expression (umpama) taken from Pakpak wedding ceremony records. The findings indicated that there were three categories of umpama Pakpak, they were: umpama related to flora, fauna, and daily activities. The total percentages of umpama for each category were: related to flora (52\%), fauna (8\%), and daily activities (16\%), while not categorized (24\%). The meaning of umpama in Pakpak wedding ceremony were containing wishes, hopes, prayers, and advices. The dominant category was related to flora $(52 \%)$.
\end{abstract}

Keywords: semantics, idiomatic expression, Pakpak wedding ceremony.

* Graduate status

** Lecturer status 


\section{INTRODUCTION}

Background of the study

A wedding is a ceremony where two people are united in marriage. Wedding traditions and customs vary greatly between cultures, ethnic groups, religions, countries, and social classes. In a marriage there is cultural structure that embodies a set of rules, views of life, values, or certain underlying principles and lives in the culture of the society in question, (Rismawati, 2011).

There are a lot of ethnic groups in North Sumatera. It is good, because the various culture that exist in a country give many good impact to another culture. We can learn from another culture and know more about culture in Indonesia. Beside that, it is also important to know more about one culture, because all cultures in this country have differences with another one.

In North Sumatera all of those ethnic groups are dominated by Batak. Batak consists of five sub ethnic groups, they are Batak Toba, Batak Karo, Batak Pakpak Dairi, Batak Mandailing/Angkola, and Batak Simalungun. In wedding ceremony of Batak Toba, there are thirteen ways of the marriage, such as mangaririt, mangalehon tanda, marhori-hori dinding, martumpol, marhata sinamot, martonggo raja, manjalo pasu-pasu parbagason, ulaon unjuk, mangihut di ampang, ditaruhon jual, paulak une, manjae, and maningkir tanda, (Sinurat, 2005).

It is different with Batak Karo that there are six things to do, such as nungkun kata, ngerana-ngerana, mbaba belo selambar, pemasu-masu, pesta adat, and 
mukul. Those are an ideal wedding in Batak Karo wedding ceremony, (Bangun, 1986).

Umpama is one of continual tradition almost in all ceremonial activities in Pakpaknese including wedding ceremony. In urban territory, people are less talking using their original language, because they are affected by their environment. When this culture is not used anymore, eventually it would be lost and extinct. When people do not know about their own culture, they would not love to their culture. People who love thier culture, they would care and want to get to know about the culture. But when people do not know about their own culture, they would never love to their culture themselves. For instance, people tend to use umpama in a wedding ceremony.

When someone does not know what umpama is, it is impossible that he likes to hear umpasa, or might be she doesn't care. This is actually the big problem that will be going to be solved. What would happen in the future when people are almost forget about their culture. Probably people would not care about the mores anymore. Those who do not care about culture would not know about the rules in a certain territory.

In Batak Toba, people believe that umpasa is a tool of ommunication for petition to God. There are three things containing in umpasa, they are to have hagabeon (sons and daughters), hamoraon (wealth), hasangapon (authority and regarded). All things contained in umpasa of Batak Toba have meaning and relationship to the human life, (Pardosi, 2008). 
Therefore, this research will be focused on idiomatic expression in Pakpak wedding ceremony. There are some expressions that will be analyzed from the wedding ceremony.

\section{REVIEW OF LITERATURE}

\section{Semantics}

Discussing about sentence meaning, we communicate with utterances, and each utterance is an instance of a sentence. But how can we explain what 'sentence meaning' is? Two points are obvious. First, the meaning of a sentence derives from the meanings of its constituent lexemes and from the grammatical meanings it contains. So if people know all the lexical and grammatical meanings expressed in a sentence, they know the meaning of the sentence, and vice versa. Second, at least if the sentence is a statement, if people know the meaning of the sentence, they know what conditions are necessary in the world for that sentence to be true, (Kreidler, 1998:56).

\section{Idiomatic Expression}

Riyadi (1994:3) defines idiomatic expression as a form of language which is a combination word meaning that can not be derived from the meaning of the combined elements or any quirks in a language. Idiom includes all expressions, strings of words as well as the wording indicates specificity in a language that distinguishes it from other languages. 


\section{Oral Tradition}

The term oral tradition is seen in different perspectives. Vansina (2015:57) describes oral tradition as "the testimony of the past which are transmitted from mouth to mouth." This connotes that oral tradition must necessarily be of the past, and transmitted through spoken words from one generation to the other. Basically, the term means the transmission of facts, values and fiction through oral means. It would not be termed "tradition", however, if it were just a momentary and temporary method of approach to historical knowledge.

\section{Proverbs}

Proverbs are wise sayings that address the heart of the discourse in any given context, truthfully and objectively. It is the short sentences that people often quote to give advice or make general comments about life. A proverb is therefore, a short well-known expression that states a general truth and gives an advice. (Joshua, 2012:47).

\section{Pakpaknese Wedding}

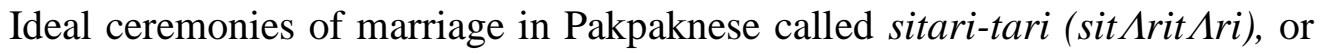
merbayo (m3:rb^yo). Once this kind of marriage should be accompanied by traditional musical (merkata genderung sipitu). This ceremony is called merbayo. This ceremony can also be called sinima-nima or memuat mende (sinim $\Lambda$ nim $\Lambda$ m3:mu^t m3:nde). Berutu (2006) states that there are some stages to pass through before ceremony of merbayo is done, as follows: 


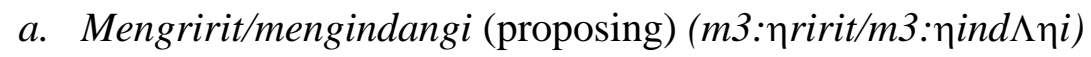

b. Mersibereen tanda burju (rings exchanging) (m3:rsib3:re:n t $\Lambda$ nd $\Lambda$ burju)

c. Menglolo / Mengkata Utang (m3: $\eta l o l o / m 3: \eta k \Lambda t \Lambda u: ' t \Lambda \eta)$

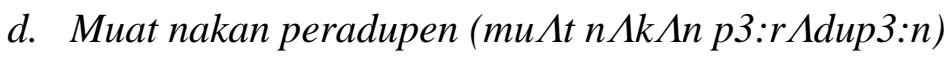

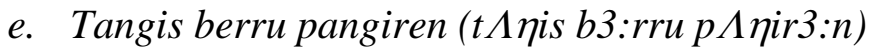

Berutu (2013:67-95) categorizes umpama Pakpak into three parts, they are umpama related to flora, umpama related to fauna, and umpama related to daily activities.

a. Related to Flora

In these kinds of umpama, Berutu uses any names of fruits, vegetables, trees, and another thing related to flora. For example:

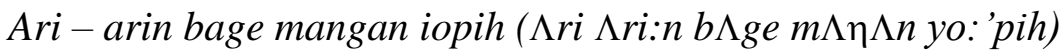

If translated lexically the meaning is 'like eating on the stem of banana'. But the purpose of this expression is actually for someone who wants something from other people without doing anything for himself.

b. Related to Fauna

In these umpama, there are kind of tiny animals, small and big. For example:

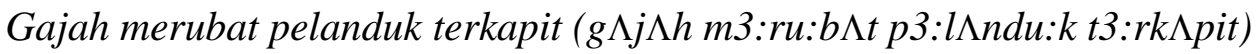

If translated lexically the meaning is 'elephants fight mouse deer impacted'. But the meaning of this umpama is aimed for the great people who cause society to suffer when they have problems. 


\section{c. Related to Daily Activities}

Umpama in this part related to all daily activities, such about job, profession or another related to that. For example:

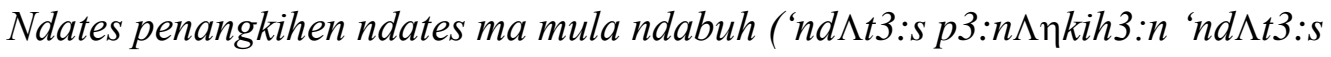
$m \Lambda$ mula: 'nd $\Lambda$ buh)

If translated lexically the menaing is 'climbing high to fall high too'. The purpose of this umpama is actually 'the higher posision of someone, the more responsibilities, risks, and challenges that he has to face.

\section{RESEARCH METHODOLOGY}

\section{Methodology}

This research was conducted by using descriptive qualitative design. Ary (2002) states descriptive qualitative method is to understand human and social behavior from the insider's perspective - that is, as it is lived by participants in a particular social setting (for example: a culture, school, community, group or institution). The purpose of this descriptive qualitative data is to create a description, illustration, facts, characteristics, and the relationship between investigated phenomenon related to the study.

The source of the data was the records of Pakpaknese wedding ceremony. 


\section{DATA AND DATA ANALYSIS}

This study deals with the description of the idiomatic expression meaning in the Pakpaknese wedding ceremony. The data were 25 utterances of idiomatic expression (umpama) from Pakpak wedding ceremony.

After collecting the data, the researcher firstly identified and then classified them based on the three categories of umpama in the wedding ceremony. Those three categories were: umpama related to flora, umpama related to fauna, and umpama related to daily activities. There was also the data which was not included into the three categories of umpama.

\section{Umpama related to flora}

\section{Umpama 1}

Banban kacimara mo nina banban kacimeru merbuah dahan parira, maseh ate Tuhan ndaoh karina mara ndaoh karina begu.

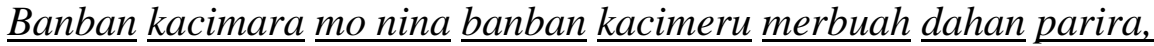

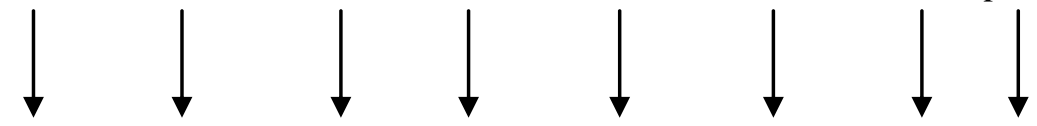

= banban kacimara is banban kacimeru fruits branch tree

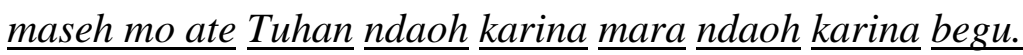

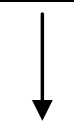

goodness

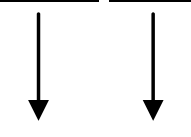

God far

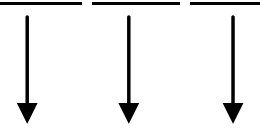

all evil far all ghost

Banban kacimara and kacimeru are the fruts and parira branch fruits, may by the goodness of God far away all the evil and ghost. 
Kacimara is a kind of plant which grows in the forest. It is far away from human, because it is not found in village territorial. Thus, everything that can irritate the works will go away from activities of all people, like kacimara far away from human. The purpose of this umpama is as a hope that conveyed to all people. The hope contains everything that is being done will be finished without any constraints to the people who do the works.

\section{Umpama related to fauna}

\section{Umpama 1}

Kabang mo nina renggisa senggep i nggala page, mangan ngo kami mbisa pemales nami oda kade.

Kabang mo nina renggisa senggep $\underline{\text { inggala page, }}$

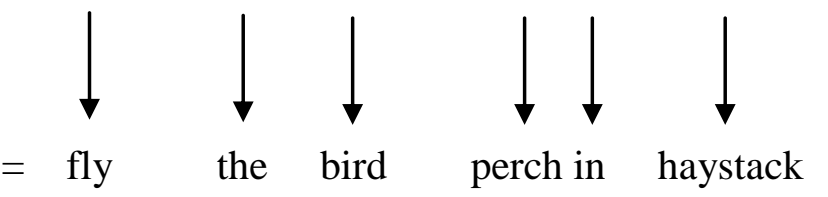

mangan ngo kami mbisa pemales nami oda kade.

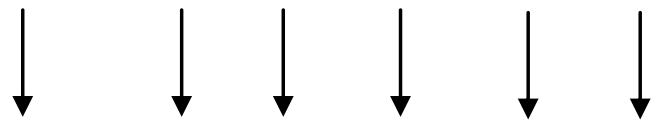

Eat we can deed our nothing

A bird flying and perching on haystack, we can eat but our deed is nothing.

Renggisa is a kind of birds which likes perching in the stack of paddy. When it perching, it usually brings nothing from its nest, and even eats anything it finds in around the paddy. This umpama is delivered by the people who received foods in a wedding ceremony. This umpama is conveyed to perberru as kula-kula in the wedding ceremony, because perberru has brought siluah like foods to peranak. In this umpama, peranak is going to say 
that they can eat only, but can not give anything as to what has been given to them by perberru.

\section{Umpama related to daily activities}

\section{Umpama 2}

Asa mpihir mo tendi ndene mi juma dekket mi rumah, ndaoh karina hali ndaoh karina habat.

$\underline{\text { Asa }} \underline{\text { mpihir mo tendi }} \underline{\text { ndene }} \underline{\text { mi juma dekket }}$ mi rumah,

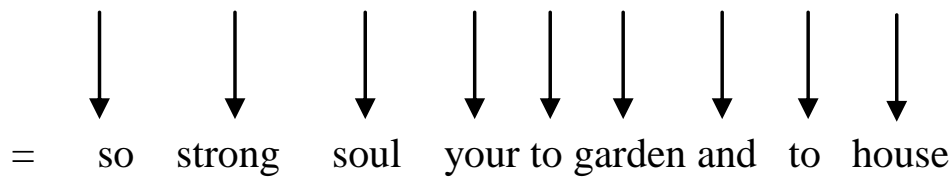

$\underline{\text { ndaoh karina hali }} \underline{\text { ndaoh karina habat. }}$

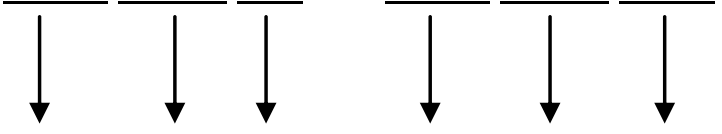

Far all disturbance far all disturbance

So your soul be strong to garden and house, far away all disturbances.

Mpihir mo tendi if translated, the meaning is a strong soul. Then if connected to the next words, there is no meaning found if someone doesn't know what the meaning of umpama itself. But actually, mpihir tendi is symbolized as a strong person. When someone is mpihir tendi, s/he is a strong person. The speaker in this umpama also hopes, that all family in the wedding ceremony will always be healthy wherever they go, whatever they do in their life. 


\section{Not categorized}

Umpama 1

Nakan sibuka-bukaen dekket merembahken roroh merorohken peddasna.

Nakan sibuka-bukaen dekket merembahken roroh merorohken peddasna.

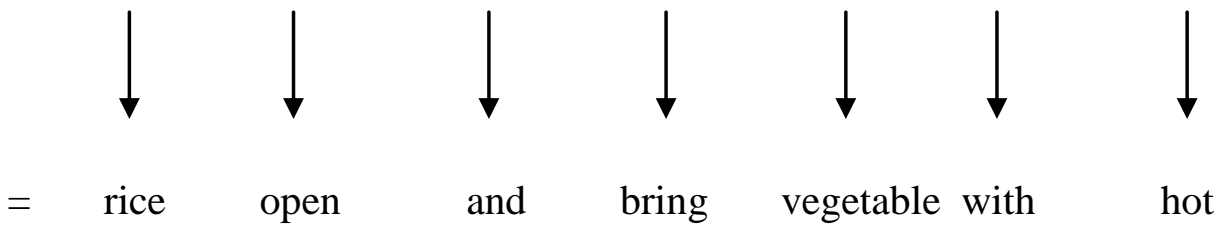

Bringing rice just opened and the vegetable still hot.

This umpama is delivered to peranak, where the side of perberru is going to give their thankfulness for the day that their daughter has become family of peranak. Nakan sibuka-bukaen means hopes, and so is merorohken peddasna. If translated, the meaning of nakan sibuka-bukaen is the rice just opened, and the meaning of merorohken peddasna is with a warm vegetable. They actually can not be separated, because they have close meaning. When rice is just opened, it is still hot, and it is added with vegetables. The purpose of this umpama is to convey hope, so that all the family of the groom side will be like nakan sibuka-bukaen merorohken peddasna. They will always be healthy, and all of fortunes and lucks will be opened to them. 


\section{CONCLUSION AND SUGGESTION}

\section{Conclusion}

After classifying and analyzing all the data, the findings of this research are concluded that:

1. All categories of umpama Pakpak were found in Pakpak wedding ceremony. They were: umpama related to flora (52\%), fauna (8\%), and daily activities (16\%). Beside of these three categories, there were also umpama found not categorized as these three categories. However, there was also umpama not categorized as these three categories.

2. The meaning of idiomatic expression (umpama) in Pakpak wedding ceremony referred to someone's feelings that conveyed to another people. That feelings can be like hopes, prayers, wishes, and advices conveyed to the family of the bride and groom's side.

\section{Suggestion}

After concluding all the results of the data, some suggestions are offered to the readers to be considered by those who are interested to study about idiomatic expression or make further research about it. They were for both theoretically and practically:

1. Theoretically, through the findings of the research, the students of English and Literature Department are suggested to learn more about idiomatic expression, especially in cultural ceremony, such wedding ceremony. 
2. Practically, the students of English and Literature Department are suggested to understand about the use of idiomatic expressions, especially in wedding ceremony.

\section{REFERENCES}

Ary, Donald, et al. 2002. Introduction to Research in Education, $6^{\text {th }}$ Edition. United States: Wadsworth

Berutu, Lister \& Tandak Berutu. 2006. Adat dan Tata Cara Perkawinan Masyarakat Pakpak. Medan: PT. Grasindo Manoratama

Berutu, Lister. 2013. Umpama, Perumpamaan \& Koning - koningen Suku Pakpak, $1^{\text {st }}$ Edition. Medan: PT. Grasindo Manoratama

Joshua, Usman, et al. 2012. Proverb As Determinant of Cultural Identity: the Imperative of the Three Regional Languages in Nigeria. International Journal of Research in Humanities, Arts and Literature. Vol.1 No.6

Kreidler, W. Charles. 2002. Introducing English Semantics. New York: Routledge

Riyadi, Slamet. 1994. Idiom Tentang Nilai Budaya Sastra Jawa. Jakarta: Pusat Pembinaan dan Pengembangan Bahasa

Rismawati. (2011). Perkawinan dan Pertukaran Batak Toba. Jurnal Academica. Vol.3 No.2.

Sinurat, Luis. (2005). Inkulturasi Ritus Perkawinan Adat Batak Toba, (tesis) Unpar: FF Unpar.

Vansina, Jan. 2014. Tradisi Lisan Sebagai Sejarah. Yogyakarta: ombak 